\title{
QUANTIFYING THE ENVIRONMENTAL IMPACT OF POLLUTANT PLUMES FROM COASTAL RIVERS WITH REMOTE SENSING AND RIVER BASIN MODELLING
}

\author{
M. LEGA ${ }^{1}$ \& T. ENDRENY ${ }^{2,3}$ \\ ${ }^{1}$ Department of Engineering, University of Naples Parthenope, Italy. \\ ${ }^{2}$ University of Naples Parthenope, Italy \\ ${ }^{3}$ SUNYESF, Syracuse, NY, USA.
}

\begin{abstract}
Coastal regions contaminated by polluted river water leaving inland river basins can be difficult to monitor due to their size and remoteness, but it is important to quantify the impact of such pollution to manage for coastal sustainability. In this research, we demonstrate how river plumes can be monitored and analysed by a combination of remote sensing and river basin modelling to estimate their spatial, temporal, and water quality characteristics. Our results show that multispectral remote sensing is able to differentiate the water quality characteristics and two-dimensional spatial characteristics between plumes from four discharge locations along the coast of Campania, Italy. Our results also show that river basin modelling, when informed by land cover, land use and wastewater treatment plant (WWTP) data, is able to estimate the plume volume, and pollutant load, attributed to rainfall-runoff and wastewater-discharge for each of the discharges. This research documents a new method for combining remote sensing and watershed modelling to quantify the environmental impact of pollution from coastal rivers. Keywords: environmental monitoring, polluted river, remote sensing, river basin modelling, river plumes, water quality.
\end{abstract}

\section{INTRODUCTION}

River and artificial channel discharge can deliver to coastal waters a wide range of pollutants due to the myriad of anthropogenic and natural biogeochemical processes on landscapes that arrive in rivers via point source and nonpoint source connections [1]. Common pollutant sources and types include sediments and nutrients from agriculture [2] and metals, hydrocarbons, organics and bacteria from wastewater [3], but there is increasing evidence of problems from emerging contaminants such as pharmaceuticals [4] and micro-plastics [5]. There are serious impacts to the environment and human well-being of pollutant loading to coastal waters, including coral reef die-back due to sediment clogging [6], fishery collapse due to hypoxia [7] and human sickness due to harmful algae blooms [8]. Climate change is predicted to worsen these problems and lead to greater discharges and disease exposure $[9,10]$.

Ecosystem-based management of coastal loading from rivers must address a range of spatial, temporal and chemical scales, and best practices include a monitoring program that connects land and sea [11]. From the sea-based perspective, remote sensing, with various radiometric sensors to cover a range of chemicals, has been used in isolation to provide the spatial and temporal coverage for monitoring river plumes into coastal areas [12], and used in combination with in-situ sampling to improve interpretability of plume water quality [13]. River plumes are often noticeable in visible and non-visible areas of the electromagnetic 
spectrum, and their morphology includes, according to Horner-Devine et al. [14]: (a) the source region where river water leaves the river mouth; (b) the lift-off region where the river water vertically lifts above denser coastal seawater; (c) the fronts where lateral contrasts in fluid density exist; (d) near-field region where the plume jets into the coastal water and initially expands, and despite buoyancy differences the momentum drives intense mixing; (e) mid-field region where the plume turns with the coastal current and plume expansion; (f) bulge where a fraction of the plume accumulates in a coastal eddy beyond the near-field or mid-field region; and (g) far-field region where buoyancy fronts exist but plume inflow momentum is inactive.

From the land-based perspective, the success of the management program depends on characterising the pollutant sources within the river basin [11]. Land use analysis in the river basin can identify likely sources of pollutants from terrestrial activities and provide managers with data needed for identifying pollutant reduction options [15]. The meteorological forcing over the river basin regulates the timing and magnitude of loads [16], as well as the dynamics of mixing at the interface of the river and sea [17]. As such, meteorological data, processed with a dynamic river basin model, can complement river basin analysis and assist in the interpretation of remote sensing imagery of river plumes in coastal waters. In this research, we present a novel combination of river basin dynamical modelling with remote-sensing image analysis to monitor the spatial, temporal and water quality characteristics of river plumes in coastal waters. The methods, results and conclusions from this research project are provided in the following sections.

\section{METHODS}

This research characterised the spatial, temporal and water quality characteristics of river plumes into coastal waters using a complementary program of remote sensing, in-situ sampling, and river basin modelling (Fig.1). While the remote-sensing approach can include imagery from satellite and aircraft, this research only reports on the use of satellite data. The satellite remote-sensing data were obtained from the Landsat 8 operational land imager sensor [18] to create normalised difference vegetation index (NDVI) images for the scene. The in-situ data water quality data were collected as part of a Campania regional government ambient coastal water sampling program [19]. The river basin dynamical modelling was performed with the i-Tree Hydro model version 5.0.10 [20], which analyses the river basin water balance using inputs of elevation data, land cover data, soil data, weather data and pollution

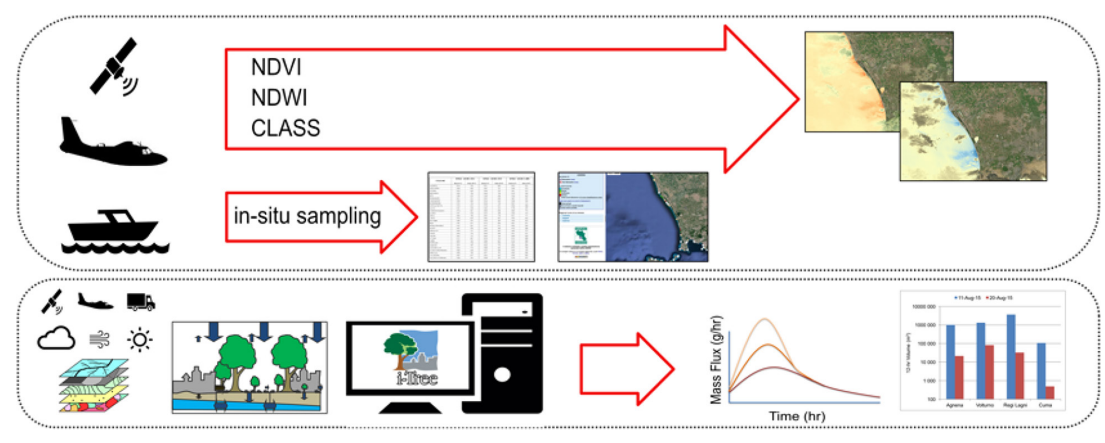

Figure 1: Combing remote sensing, in-situ and modelling methods. 
data. These methods were applied to a set of study sites in Italy to analyse a river to coastal water discharge episode on 11 August 2015.

The study sites for this research were in the Campania region of Italy, and included the river basins of Agnena (500 km² in area), Volturno (5623 km² in area), Regi Lagni $\left(1123 \mathrm{~km}^{2}\right.$ in area) and Cuma ( $7 \mathrm{~km}^{2}$ in area), each along the Mediterranean Sea (Fig. 2). Each of these river basins has artificial channels, most installed to drain wetland areas and connecting to the main river, but in Cuma, a concrete channel was installed to convey discharge from a wastewater treatment plant (WWTP) directly to the sea. The Cuma artificial channel connects to the sea at the southwestern edge of the basin, while the natural channel discharges from the north-western edge of the basin. The Cuma WWTP has an effluent flowrate of $4.2 \mathrm{~m}^{3} / \mathrm{s}$ to $5.7 \mathrm{~m}^{3} / \mathrm{s}$ during dry weather and a maximum flow rate of $12 \mathrm{~m}^{3} / \mathrm{s}$ during wet weather [21]. The Regi Lagni river basin has five WWTPs, but all discharge directly to the main river. Artificial drainage channels in Volturno river basin resulted in the creation of the Agnena and Regi Lagni river basins, which historically had joined the Volturno mainstream river.

To obtain elevation data, land cover data and weather data for the four study sites, the boundary for the study site was determined using polygon boundary files. The boundary files representing the artificial drainage networks were obtained from pre-processed data for the

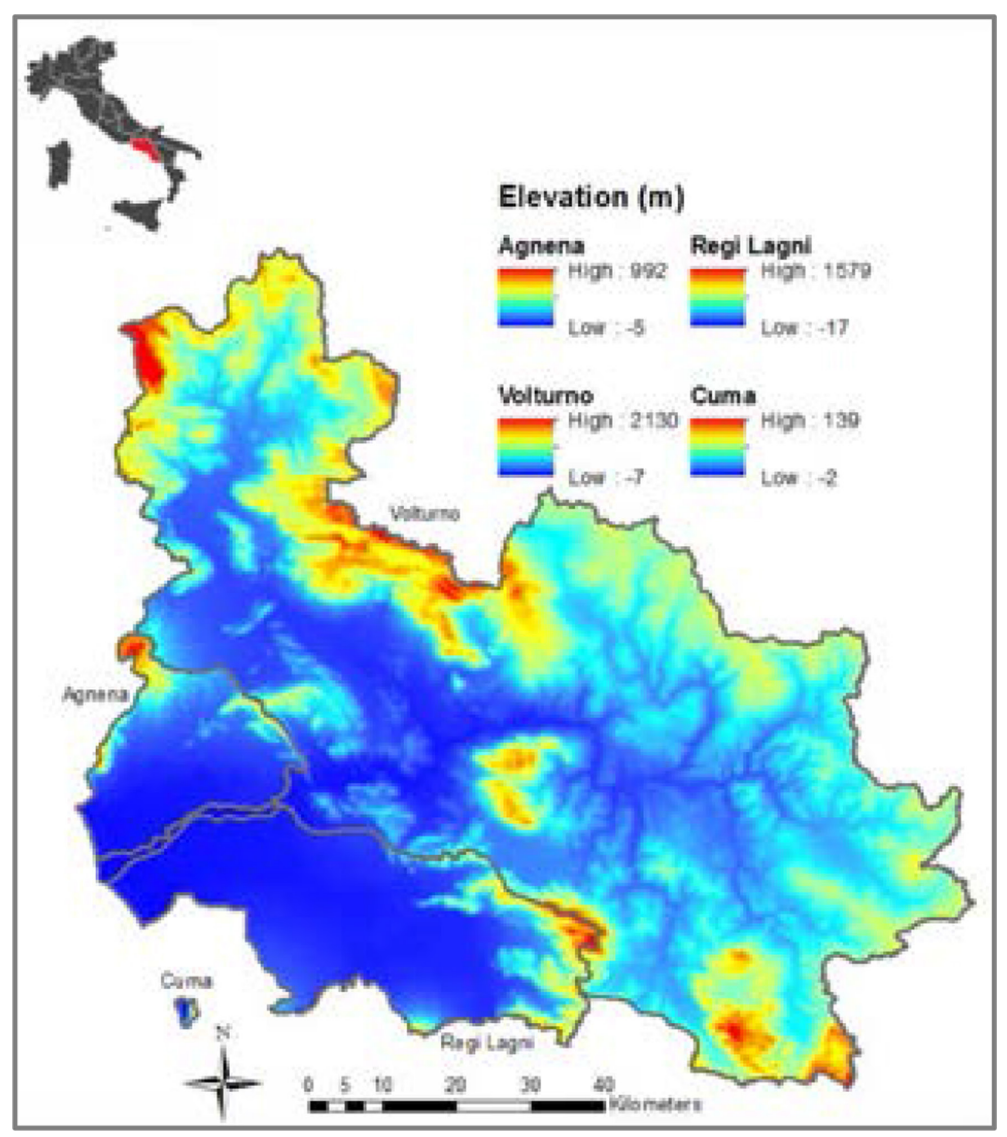

Figure 2: Study sites with elevation data, in Campania Italy. 
Agnena, Volturno, and Regi Lagni river basins [22]. The boundary file for the Cuma river basin was delineated in our research using Shuttle Radar Topography Mission (SRTM) version 2.1 data [23], which has 3 arc-second resolution, or $81.9 \mathrm{~m}$ pixel resolution when converted to ETRS 1989 UTM Zone 33N for use at this study site. The SRTM elevation data for each river basin was then clipped to the boundary file, and the i-Tree Hydro model converted these data into topographic index values used in implementing the TOPMODEL-based water balance [24]. The Corine Land Cover 2006 seamless vector data [22] were analysed for each river basin to determine the eight land cover classes used in i-Tree Hydro, which are forest, shrub, herbaceous, water, impervious and soil, as well as percent of forest in evergreen tree and percent of shrub in evergreen shrub (Table 1). Each of the basins had $25 \%$ of more forest cover, $33 \%$ or more herbaceous (which includes agriculture), and Agnena and Volturno had less than 6\% impervious while Regi Lagni and Cuma had more than $24 \%$ impervious cover.

Air temperature, relative humidity, cloud cover and other non-precipitation weather data were obtained from the National Climate Data Center for the entire 2015 calendar year using a single station at Grazzanise, Italy, which was the only station used all four river basins. These weather station data were then processed at a 1-h time step to obtain hourly estimates of evaporation and evapotranspiration for the i-Tree Hydro model. Precipitation data were a combination of IMERG and TRMM satellite remote-sensing products, both obtained from the Giovanni Earth Data portal. The IMERG product provided 30-min temporal resolution and $0.1^{\circ}$ spatial resolution for the 21 days centered on 11 August 2015. The TRMM product provided a coarser temporal and spatial resolution $\left(3 \mathrm{~h}, 0.25^{\circ}\right)$, but was easier to download and process. The Giovanni TRMM data were converted from a 3-h to 1-h time step for use in i-Tree Hydro by assigning the entire $3 \mathrm{~h}$ depth to $1 \mathrm{~h}$ if the 3 -h observation had no precipitation before or after in time, and otherwise assigned $1 / 3$ of the 3 -h depth to each of the corresponding 1-h periods.

Table 1: Area, land cover and climate conditions by river basin.

\begin{tabular}{lllll}
\hline & Agnena & Volrurno & Regi Lagni & Cuma \\
\hline River Basin Area (sq km) & 200 & 5623 & 1122.5 & 7.1 \\
Land Cover & & & & \\
Forest (\%) & 29.2 & 35.5 & 30.1 & 25.7 \\
Shrup (\%) & 4.1 & 4.6 & 1.6 & 2.9 \\
Herbaceous (\%) & 61.1 & 55.6 & 43.3 & 33.4 \\
Water (\%) & 0.1 & 0.2 & 0.1 & 0.0 \\
Impervious (\%) & 5.1 & 3.1 & 24.2 & 37.1 \\
Soil (\%) & 0.4 & 1.0 & 0.6 & 1.0 \\
Evergreen Tree (\%) & 4.2 & 9.9 & 6.4 & 8.3 \\
Evergreen Shrub (\%) & 48.7 & 7.6 & 19.4 & 100 \\
Climate & & & & \\
Annul precipitation (mm) & 848 & 884 & 1004 & 10041 \\
5 d prior precipitation & 80 & 60 & 113 & 200 \\
11 Aug 15 (mm) & & & & \\
\hline
\end{tabular}


Climate for the region of Campania which contains the study site river basins is classified as hot-summer Mediterranean, with Koppen-Geiger classifications of coastal and interior Mediterranean. The region has an average annual temperature of $15.2^{\circ} \mathrm{C}$ and average annual precipitation of $901 \mathrm{~mm}$ [25]. For 2015, the Grazzanise weather station had an average air temperature of $16.6^{\circ} \mathrm{C}$, with a maximum air temperature of $39.4^{\circ} \mathrm{C}$ in July and a minimum air temperature of $-5.1^{\circ} \mathrm{C}$ in January. Based on the Giovanni data for Agnena, the precipitation 5 days prior to August 11 was $80 \mathrm{~mm}$, and for the 5-days prior to the 11 August 2015 event the four sites had between 60 and $200 \mathrm{~mm}$ of precipitation, or $7 \%-20 \%$ of their annual total precipitation (Table 1).

To estimate the discharge of 11 August 2015, the i-Tree Hydro model simulated the entire 2015 year, in order to spin-up the river basin water balance and remove the effect of initial conditions. The i-Tree Hydro model was calibrated to match the regional runoff ratio; no observed data were available for the four study site river basins, so runoff ratios were used. The initial soil parameter values were estimated as blend of hydrologic soil groups B and C, based on work of Del Giudice et al. [26] and assigned the texture class silt loam for the i-Tree Hydro simulation. The Del Giudice et al. [26] data were also used to estimate the runoff ratio for the river basins. The calibration exercises resulted in final parameter values for each river basin that were used to estimate the discharge during the 2015 year and the specific date of 11 August 2015. The i-Tree Hydro model has default pollutant estimate values from the event mean concentration studies [27], which provide estimates of river loads for total suspended solids, metals and nutrients. Bacteria loads for faecal indicator organisms (FIO) from the river basins were estimated by combining i-Tree Hydro estimates of discharge with FIO export coefficient values developed using more than 200 river basins with varying land cover and climate in the United Kingdom [28].

The Landsat 8 multi-spectral data from 11 August 2015 was pre-processed with atmospheric correction routines, then used to compute NDVI, and finally pan-sharpened to $15 \mathrm{~m}$ for image analysis. The NDVI was computed as: , where NIR is the near infrared band and R is the red band, and output will range from -1 to 1 . Typically, NDVI values between 0 and 1 are used for analysis of vegetation on the terrestrial surface, and negative values are discarded. However, researchers use NIR and R bands to monitor aquatic algal blooms [29]. In this research, the -1 to 1 range of NDVI values were analysed for the water surface, in an effort to identify the potential for algal blooms, the delivery of algae and photosynthetic matter from the terrestrial source, as well as materials sensitive to the NIR and R contrast. Ten classes of NDVI were generated for the scene to illustrate different intensities of possible photosynthetic activity in the river plume, with classes 1 to 3 set to highlight the river plume fronts and near field regions, as well as other plume geometry. The analysis of the NDVI image was limited to pixels bounded by at least 1 other pixel fully in the water area, to reduce the chance of analysing pixels with spectral signatures influenced by terrestrial radiation.

\section{RESULTS AND DISCUSSION}

The NDVI classification for the coastal area on 11 August 2015 identified river plumes associated with each of the river basins [Fig. 3]. Moving from north to south in along the coast, the Agnena river basin has the most diffuse plume shape (following NDVI classes 1 to 3 ) and is possibly surrounded by seepage from the coastal area. For Agnena, the NDVI analysis generated an estimated area of $2.16 \mathrm{~km}^{2}$. South of Agnena is the Volturno river basin, with a clearly defined plume that is centred on the river mouth and may include seepage from the coast. For Volturno, the NDVI analysis generated an estimated area of $4.82 \mathrm{~km}^{2}$. South of 


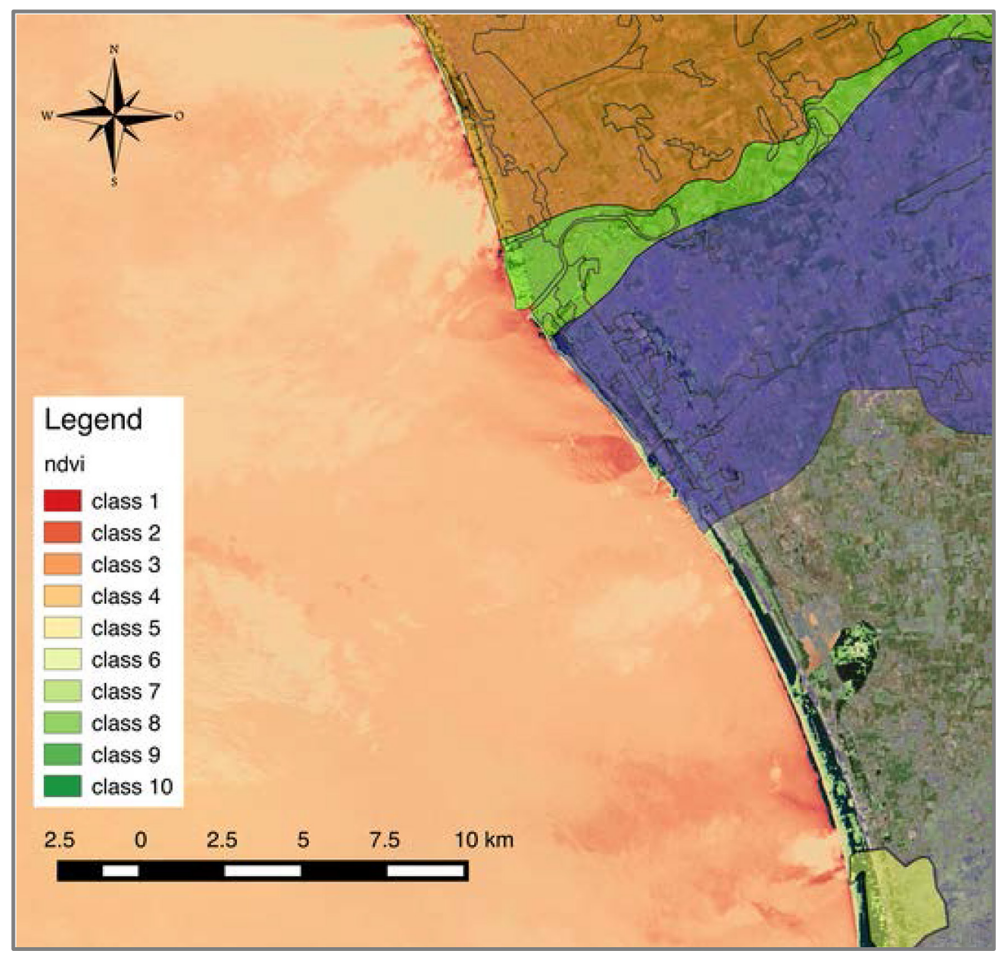

Figure 3: Landsat 8 NDVI classes to reveal plumes near study sites.

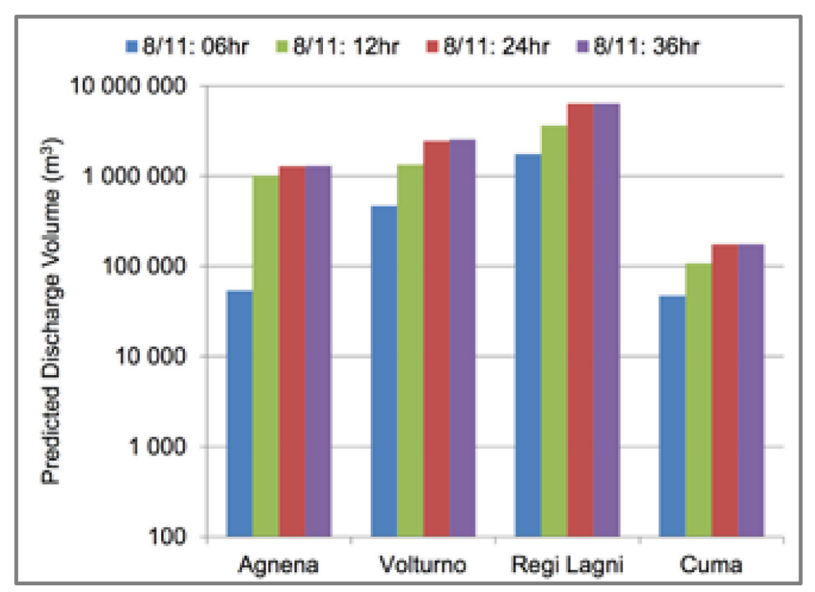

Figure 4: (L) Predicted plume volume from rivers for four durations.

Volturno is the Regi Lagni river basin, with a clearly defined plume centred on the river mouth. For RegiLagni, the NDVI analysis generated an estimated area of $2.92 \mathrm{~km}^{2}$. In the southern most section of the image is the Cuma river basin, with a clearly defined, narrow, plume jetting into the coastal area from its northern channel, and then there is evidence of 
seepage from the land area between Cuma and RegiLagni. For Cuma, the NDVI analysis generated an estimated area of $0.39 \mathrm{~km}^{2}$.

The i-Tree Hydro model estimated the total discharge from each river basin for 6, 12, 24 and 36-h durations prior to 12:00 on 11 August 2015, allowing for analysis of the possible range of volumetric river water loading that was within the plume area (Fig. 4). The Cuma river basin discharged 47,000 $\mathrm{m}^{3}$ during $6 \mathrm{~h}$, and 176,000 $\mathrm{m}^{3}$ during $36 \mathrm{~h}$, which were the smallest volumes of all basins. By contrast, the Regi Lagni river basin, which received the greatest 5-day prior precipitation and had the largest discharge volumes, discharged 1.76 million $\mathrm{m}^{3}$ of river water in the 6-h period, and 6.4 million $\mathrm{m}^{3}$ in the $36-\mathrm{h}$ period. Based on the largest difference in volume for each river basin occurring between the 6 and $12 \mathrm{~h}$ duration, the NDVI scene captured a period of intense runoff and plume advection into the coast. The volumes of discharge were converted to areas of discharge (Fig. 5) by setting an average mix-

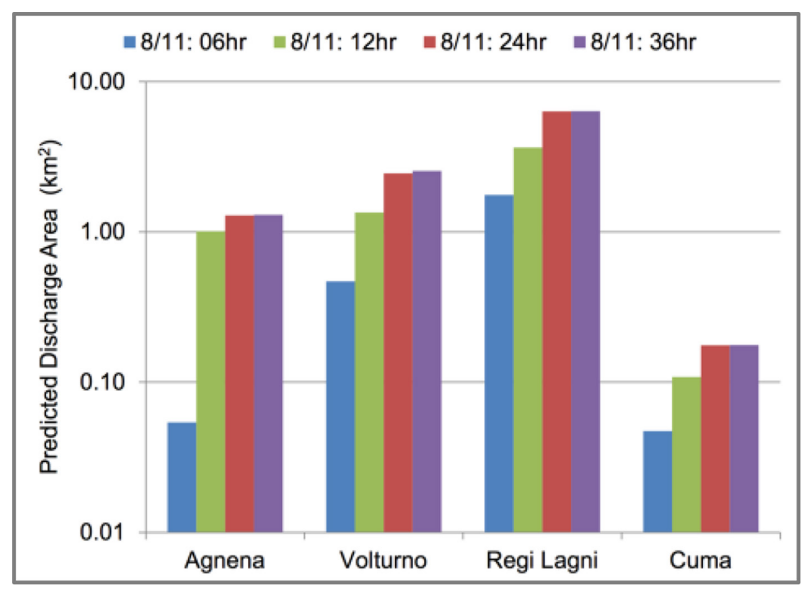

Figure 5: (R) Predicted areas of plumes from rivers for four durations.

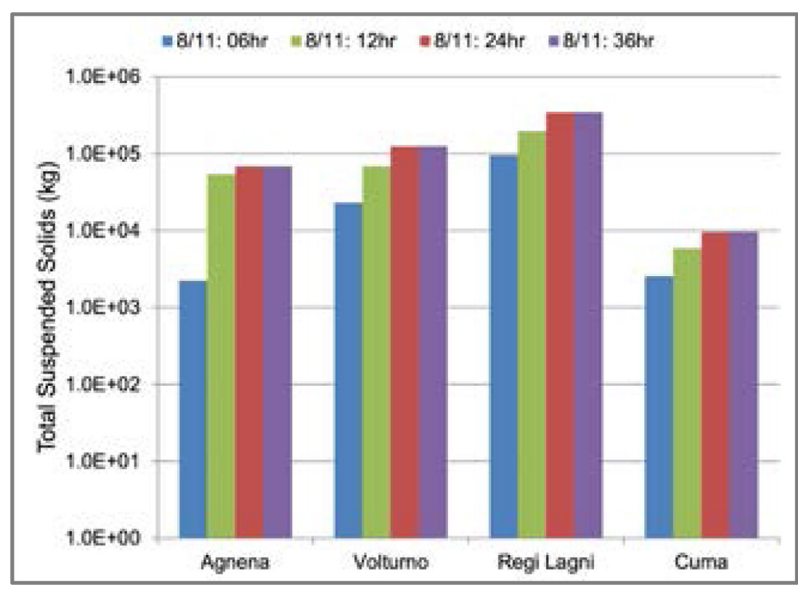

Figure 6: (L) Predicted TSS in plumes from rivers for four durations. 


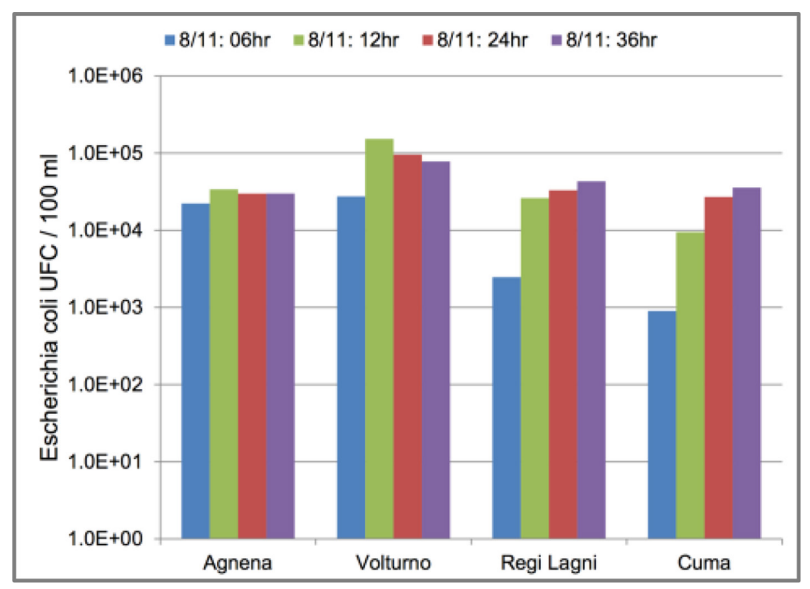

Figure 7: (R) Predicted E. coli in rivers plumes for four durations.

ing depth of $0.5 \mathrm{~m}$. At the 12-h duration, the plumes had nearly reached their maximum spatial extent, and for Agnena it was $1.01 \mathrm{~km}^{2}$, for Volturno it was $1.34 \mathrm{~km}^{2}$, for Regi Lagni it was $3.64 \mathrm{~km}^{2}$ and for Cuma it was $0.11 \mathrm{~km}^{2}$. These i-Tree Hydro estimates were mostly biased low, and ranged from $27 \%$ to $124 \%$ of the plume area defined by the NDVI classes 1 to 3 , and a better approximation is likely achievable by calibrating the NDVI and i-Tree Hydro methods, or pursuing an inverse solution to solve for mixing depth.

The pollutant estimates within the river plumes were estimated by i-Tree Hydro for total suspended solids, TSS (Fig. 6) and Escherichia coli (Fig. 7). In the Agnena river basin, the TSS data load ranged from $2200 \mathrm{~kg}$ to $68,000 \mathrm{~kg}$ for the $6-36 \mathrm{~h}$ durations; the Regi Lagni river basins discharged the greatest load, at $340,000 \mathrm{~kg}$ of TSS in $24 \mathrm{~h}$. For all river basins, the TSS load was correlated to the discharge, and the greatest change in loading occurred between 6 and $12 \mathrm{~h}$, and no significant loading was added between 24 and $36 \mathrm{~h}$. This i-Tree Hydro estimate captures only TSS generated during runoff from precipitation events and neglects the wash load that can be transported during low energy flows, called baseflow. The $E$. coli loading was computed for precipitation generated during runoff and for baseflow, using different export coefficient values for each [28]. The Escherichia coli values for the 6-h duration were as low as $898 \mathrm{UFC} / 100 \mathrm{~mL}$ for the Cuma, were $2471 \mathrm{UFC} / 100 \mathrm{~mL}$ for the RegiLagni, were $27,401 \mathrm{UFC} / 100 \mathrm{~mL}$ for the Volturno and were 22,242 UFC/100 mL for the Agnena. These predicted loads were for the mouth of the river, and did not incorporate estimates of mixing and dilution. Observed loads in the coastal waters, measured by in-situ sampling by ship between the 10th and the 12th of August 2015, were 2005 UFC/100 mL near Cuma, 2005 UFC/100 mL near RegiLagni, 429 UFC/100 mL near Volturno and 478 UFC/100 mL near Agnena. There is a clear over-estimation of E. coli loads for Agnena and Volturno, which is attributed to a lack of calibration of the model to differentiate between export coefficient values for high versus low flows. In addition, the UK-based export coefficient values for E. coli may not work well in the distinctly different August climate of Campania, Italy.

For several pollutants, precipitation will affect the loading rates. In a study of short intense precipitation, it was observed to increase volumetric loading by $60 \%-150 \%$ at two French WWTPs and increase loads of arsenic and lead between $70 \%$ and $200 \%$ [16], which would then potentially lead to larger pollutant levels in receiving water rivers and their plumes. Additional pollutants not simulated in this study, but that could be affecting water quality, 
include chemicals from olive oil production, such as phenols, ammonium and phosphorus, which were observed to degrade aquatic ecosystems in the olive oil production area of Messinia, Greece [30]. This study also did not estimate the pollutants from the WWTPs in the river basins; for the Cuma river basin those pollutants in the influent are estimated to have a BOD 320 mg/l, TSS 160 mg/l, N-NH4+ 28 mg/l, N-NO3- 0 mg/l, total P 6 mg/l [21].

Mixing of the river plume and the coastal water was not simulated in this research, but such mixing can be included in a monitoring program to improve estimates of coastal water plume extent and concentrations. Physical drivers regulating the spatial extent of the river plume into the coastal waters, and its rate of dilution, include the river flow rate and initial momentum, buoyancy differences in the mixing area, and the entrainment of low momentum coastal water into the near-field region, which depends on the tidal and wave amplitude along the coast, the depth and slope of the coastal zone, the wind velocity vectors, and the coastal circulation patterns [17]. Models can be used to estimate vertical mixing and horizontal transport of the plume. Vertical mixing is the primary driver of plume dilution, and this mixing will increase decrease differences in buoyancy and water quality between the coastal and river waters [17]. Horizontal advection is the primary driver of plume transport into the coast, and this is initially driven by momentum in the near-field region, and then driven by buoyancy gradients, wind stress, and coastal currents in the far-field region [17].

Plume and coastal mixing impacts the concentrations of $E$. coli in the water, which was demonstrated by in Fortaleza, Brazil by a group that simulated initial dilution, dispersion, and solar-decay with a hydrodynamic model [31]. Based on their analysis, the initial dilution from a submerged outfall was observed to vary with currents, and ranged between 126 and 1047, with lower values during effluent discharge periods and higher values during strong winds and currents. Decay rates ranged with sunlight, and daytime $\mathrm{T}_{90}$ decay ranged from 2 to $20 \mathrm{~h}$ and night-time $\mathrm{T}_{90}$ decay ranged from 22.5 to $100 \mathrm{~h}$ [31]. However, other studies have concluded that coastal currents had little effect on pollutant plume dispersion in coastal waters [3]. According to the analysis of Stark et al.[3], the pollutant plume travelled along the coast and its chemistry was detected in the water column at $1.5 \mathrm{~km}$ from the outfall chemistry. These physical processes could be included in dynamical analysis to improve water quality estimates.

There are several other remote-sensing data products that can be used in the environmental monitoring, including fusion of optical data with synthetic aperture radar data to detect cattle ranching [32] and use of thermal imagery to monitor landfills [33] and detect illegal dumping [34]. In addition, remote-sensing data can be strategically combined with other data layers in geographic information systems to monitor the vulnerability of cultural sites [35] and anticipate environmental violations [36].

\section{CONCLUSIONS}

This research combined two-dimensional remotely sensed NDVI maps with in-situ point measurements of water quality measurements and dynamic river basin simulation of discharge volumes and identification of pollutant types and sources to characterise the spatial, temporal and chemical scope of pollution events in coastal waters. Combining the river basin dynamic simulation with the remote-sensing imagery allowed for complementary perspectives in quantifying the pollutant loading to the coastal waters, and through calibration of these tools, can lead to improved environmental quality.

\section{ACKNOWLEDGEMENTS}

The authors are grateful for the support from the United States and Italy Fulbright Commission, who have facilitated this collaboration with a travel grant. The authors are also grateful for 
the support from the Agency for Environmental Protection (ARPA) of the Campania region, Italy for providing additional imagery used in this larger research project.

\section{REFERENCES}

[1] Tappin, A.D. \& Millward, G.E., The english channel: contamination status of its transitional and coastal waters. Marine Pollution Bulletin, 95(2), pp. 529-550, 2015. http://dx.doi.org/10.1016/j.marpolbul.2014.12.012

[2] Nunnally, C.C., Rowe, G.T., Thornton, D.C.O. \& Quigg, A., Sedimentary oxygen consumption and nutrient regeneration in the northern gulf of mexico hypoxic zone. Journal of Coastal Research, pp. 84-96, 2013.

http://dx.doi.org/10.2112/SI63-008.1

[3] Stark, J.S., Bridgen, P., Dunshea, G., Galton-Fenzi, B., Hunter, J., Johnstone, G., King, C., Leeming, R., Palmer, A., Smith, J., Snape, L., Stark, S. \& Riddle, M., Dispersal and dilution of wastewater from an ocean outfall at davis station, Antarctica, and resulting environmental contamination. Chemosphere, 152, pp. 142-157, 2016.

http://dx.doi.org/10.1016/j.chemosphere.2016.02.053

[4] Jiang, J.J., Lee, C-L., Fang, M-D., Tu, B-W. \& Liang, Y-J., Impacts of emerging contaminants on surrounding aquatic environment from a youth festival. Environmental Science \& Technology, 49(2), pp. 792-799, 2015.

http://dx.doi.org/10.1021/es503944e

[5] Frias, J., Gago, J., Otero, V. \& Sobral, P., Microplastics in coastal sediments from Southern Portuguese shelf waters. Marine Environmental Research, 114, pp. 24-30, 2016. http://dx.doi.org/10.1016/j.marenvres.2015.12.006

[6] Restrepo, J.D., Park, E., Aquino, S. \& Latrubesse, E.M., Coral reefs chronically exposed to river sediment plumes in the southwestern Caribbean: Rosario Islands, Colombia. Science of the Total Environment, 553, pp. 316-329, 2016. http://dx.doi.org/10.1016/j.scitotenv.2016.02.140

[7] Diaz, R.J. \& Rosenberg, R., Marine benthic hypoxia: a review of its ecological effects and the behavioural responses of benthic macrofauna. In Oceanography and Marine Biology - an Annual Review, Vol 33, eds. Ansell, A.D., Gibson, R.N \& Barnes, M., U C L Press Ltd: London, pp. 245-303, 1995.

[8] Codd, G.A., Morrison, L.F. \& Metcalf, J.S., Cyanobacterial toxins: risk management for health protection. Toxicology and Applied Pharmacology, 203(3), pp. 264-272, 2005. http://dx.doi.org/10.1016/j.taap.2004.02.016

[9] Hernandez-Delgado, E.A., The emerging threats of climate change on tropical coastal ecosystem services, public health, local economies and livelihood sustainability of small islands: cumulative impacts and synergies. Marine Pollution Bulletin, 101(1), pp. 5-28, 2015. http://dx.doi.org/10.1016/j.marpolbul.2015.09.018

[10] Patz, J.A., Vavrus, S.J., Uejio, C.K. \& McLellan, S.L., Climate change and waterborne disease risk in the great lakes region of the US. American Journal of Preventive Medicine, 35(5), pp. 451-458, 2008. http://dx.doi.org/10.1016/j.amepre.2008.08.026

[11] Guerry, A.D., Icarus and daedalus: conceptual and tactical lessons for marine ecosystem-based management. Frontiers in Ecology and the Environment, 3(4), pp. 202-211, 2005.

http://dx.doi.org/10.1890/1540-9295(2005)003[0202:IADCAT]2.0.CO;2 
[12] Petus, C., Marieu, V., Novoa, S., Chust, G., Bruneau, N. \& Froidefond, J.M., Monitoring spatio-temporal variability of the Adour River turbid plume (Bay of Biscay, France) with MODIS 250-m imagery. Continental Shelf Research, 74, pp. 35-49, 2014. http://dx.doi.org/10.1016/j.csr.2013.11.011

[13] Devlin, M.J., Petus, C., Silva, E., Tracey, D., Wolff, N.H., Waterhouse, J. \& Brodie, J., Water quality and river plume monitoring in the great barrier reef: an overview of methods based on ocean colour satellite data. Remote Sensing, 7(10), pp. 12909-12941, 2015. http://dx.doi.org/10.3390/rs71012909

[14] Horner-Devine, A.R., Hetland, R.D. \& MacDonald, D.G., Mixing and transport in coastal river plumes. In Annual Review of Fluid Mechanics, Vol 47, eds. Davis, S.H \& Moin, P. 569-594, 2015. http://dx.doi.org/10.1146/annurev-fluid-010313-141408

[15] Shields, K., Fischer, A. \& Burke, C., Toward an improved ecosystem based management approach: incorporating catchment characteristics into better management and planning of the Great Barrier Reef marine ecosystem. Journal of Environmental Planning and Management, 58(7), pp. 1270-1290, 2015. http://dx.doi.org/10.1080/09640568.2014.921143

[16] Deycard, V.N., Schafer, J., Blanc, G., Coynel, A., Petit, J.C.J., Lanceleur, L., Dutruch, L., Bossy, C. \& Venture, A., Contributions and potential impacts of seven priority substances (As, $\mathrm{Cd}, \mathrm{Cu}, \mathrm{Cr}, \mathrm{Ni}, \mathrm{Pb}$, and $\mathrm{Zn}$ ) to a major European Estuary (Gironde Estuary, France) from urban wastewater. Marine Chemistry, 167, pp. 123-134, 2014. http://dx.doi.org/10.1016/j.marchem.2014.05.005

[17] Horner-Devine, A.R., Hetland, R.D. \& MacDonald, D.G., Mixing and transport in coastal river plumes. Annual Review Of Fluid Mechanics, 47, pp. 569-594, 2015.

[18] USGS. Landsat 8: Instruments and Products. 2016; Available at: http://landsat.usgs. gov/landsat8.php

[19] ARPA Campania. Acque di Balneazione: mappa interattiva. 2016; Available at: http:// balneazione.arpacampania.it/balneazione/index.asp

[20] Yang, Y., Endreny, T.A. \& Nowak, D.J., i-tree hydro: snow hydrology update for the urban forest hydrology model. Journal of the American Water Resources Association (JAWRA), 47(6), pp. 1211-1218, 2011. http://dx.doi.org/10.1111/j.1752-1688.2011.00564.x

[21] ENEA. Progetto Regi Lagni: Volume 2 - Stato Della Qualità Delle Acque, Rapporto Sullo Stato Delle Infrastrutture Igienico-sanitarie. 2016; Available from: http://www. bologna.enea.it/ambtd/regi-lagni/volume-2/4-vol2-stato_infr-cuma.html.

[22] MinAmbiente. The National Geoportal: Visualizzatori Cartografici. 2016; Available at http://www.pcn.minambiente.it/GN/en/

[23] NASA JPL. Shuttle Radar Topography Mission 2016; Available from: http://www2.jpl. nasa.gov/srtm/cbanddataproducts.html

[24] Wang, J., Endreny, T.A. \& Hassett, J.M., Power function decay of hydraulic conductivity for a TOPMODEL-based infiltration routine. Hydrological Processes, 20(18), pp. 3825-3834, 2006. http://dx.doi.org/10.1002/hyp.6159

[25] ClimateData.Org. Climate Data for Cities Worldwide. 2016. Available at: http:// en.climate-data.org/ 
[26] Del Giudice, G., Padulano, R. \& Rasulo, G., Spatial prediction of the runoff coefficient in Southern Peninsular Italy for the index flood estimation. Hydrology Research, 45(2), pp. 263-281, 2014. http://dx.doi.org/10.2166/nh.2013.243

[27] USEPA, Results of the Nationwide Urban Runoff Program: Volume 1 - Final Report. U.S. Environmental Protection Agency, Water Planning Division: Washington, DC, 1983.

[28] Kay, D., Crowther J., Stapleton, C.M., Wyer, M.D., Fewtrell, L., Anthony, S., Bradford, M., Edwards, A., Francis, C.A., Hopkins, M., Kay, C., McDonald, A.T., Watkins, J. \& Wilkinson, J., Faecal indicator organism concentrations and catchment export coefficients in the UK. Water Research, 42(10-11), pp. 2649-2661, 2008.

http://dx.doi.org/10.1016/j.watres.2008.01.017

[29] Hu, C.M., A novel ocean color index to detect floating algae in the global oceans. Remote Sensing of Environment, 113(10), pp. 2118-2129, 2009. http://dx.doi.org/10.1016/j.rse.2009.05.012

[30] Pavlidou, A., Anastasopoulou, E., Dassenakis, M., Hatzianestis, I., Paraskevopoulou, V., Simboura, N., Rousselaki, E. \& Drakopoulou., Effects of olive oil wastes on river basins and an oligotrophic coastal marine ecosystem: a case study in Greece. Science of the Total Environment, 497, pp. 38-49, 2014.

http://dx.doi.org/10.1016/j.scitotenv.2014.07.088

[31] Pereira, S.P., Rosman, P.C.C., Alvarez, C., Schetini, C.A.F., Souza, R.O. \& Vieira, R.H.S.F., Modeling of coastal water contamination in Fortaleza (Northeastern Brazil). Water Science and Technology, 72(6), pp. 928-936, 2015.

http://dx.doi.org/10.2166/wst.2015.292

[32] Errico, A., Angelino, C.V., Cicala, L., Persechino, G., Ferrara, C., Lega, M., Vallario, A., Parente, C., Masi, G., Gaetano, R., Scarpa, G., Amitrano, D., Ruello, G., Verdoliva, L. \& Poggi, G., Detection of environmental hazards through the feature-based fusion of optical and SAR data: a case study in southern Italy. International Journal of Remote Sensing, 36(13), pp. 3345-3367, 2015.

http://dx.doi.org/10.1080/01431161.2015.1054960

[33] Lega, M. \& Napoli, R.M.A., A new approach to solid waste landfills aerial monitoring. WIT Transactions on Ecology and the Environment, 109, pp. 193-199, 2008. http://dx.doi.org/10.2495/WM080211

[34] Persechino, G., Lega, M., Romano, G., Gargiulo, F. \& Cicala, L., An advanced tool to investigate illegal dumping. WIT Transactions on Ecology and the Environment, 173, pp. 603-614, 2013.

[35] Lega, M. \& Persechino, G., GIS and infrared aerial view: advanced tools for the early detection of environmental violations. WIT Transactions on Ecology and the Environment, 180, pp. 225-235, 2014. http://dx.doi.org/10.2495/WM140191

[36] Lega, M., d'Antonio, L. \& Napoli, R.M.A., Cultural heritage and waste heritage: advanced techniques to preserve cultural heritage, exploring just in time the ruins produced by disasters and natural calamities. WIT Transactions on Ecology and the Environment, 140, pp. 123-134, 2010.

http://dx.doi.org/10.2495/WM100121 